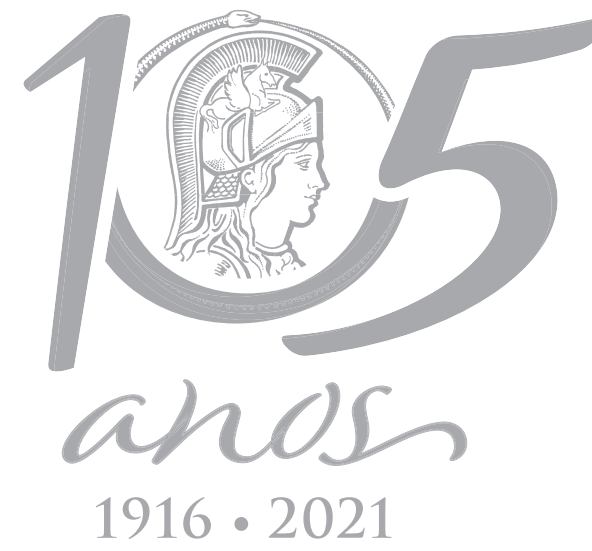

$1916 \cdot 2021$

\title{
ECOSYSTEMS
}

\section{New insights on the relation between zooplankton and humic substances in tropical freshwater ecosystems}

\author{
CLARICE C. NOVA, ADRIANA M. ROCHA, CHRISTINA W.C. BRANCO \& REINALDO L. \\ BOZELLI
}

\begin{abstract}
Aquatic humic substances (HS) represent about $60-95 \%$ of the dissolved organic carbon (DOC) present in coastal environments of northern Rio de Janeiro state, Brazil. Although they are important regulators of processes involving aquatic communities, the response of the zooplankton community to their presence remains poorly understood, especially in natural tropical environments. Therefore, our objective was to elucidate zooplankton community responses along a natural gradient of HS. Such natural humic gradient was obtained in coastal freshwater environments with distinct DOC concentrations (20-200 mg L-1). Results show a decrease in zooplankton density and biomass along the HS gradient. However, microphages organisms (e.g. non-predatory rotifers and smaller testate amoeba, such as Difflugia) were most present in environments with higher concentration of HS, probably due to a stronger importance of the microbialloop in these environments. Some species - such as Scapholeberis armata (Cladocera) and Lecane boettgeri (Rotifera) were only accounted for environments with high HS concentration, illustrating their potential as bioindicators for HS presence. Nevertheless, we were able to observe the effects of HS on the structure and composition of primary consumers and how these substances might indirectly affect species dynamics. We point out to new findings in highly humic tropical environments, which are still poorly studied and understood.
\end{abstract}

Key words: Blackwater, dissolved organic carbon, plankton, primary consumers.

\section{INTRODUCTION}

Humic substances (HS) are heterogeneous compounds with high molecular weight, biologically stable and which have a coloring trait, formed in the environment as a byproduct of organic matter decomposition (Druvietis et al. 1998). These substances are complex organic molecules which represent most (up to 95\%) of the dissolved organic carbon in aquatic ecosystems (Wetzel 2001, Steinberg et al. 2006) reaching this percentual contribution in tropical coastal ecosystems (Farjalla et al. 2009). HS are present in all aquatic ecosystems, in higher or smaller concentrations, in the form of dissolved molecules, colloids and particulate matter (Kronberg 1999).

HS have been historically considered biologically inert substances in aquatic ecosystems and their ecological functions are generally related to nutrients bioavailability, $\mathrm{pH}$ control and light penetration (Steinberg et al. 2006, Steinberg 2003). However, due to these effects on the water column, these substances may act limiting the autotrophic primary production and its related food web (Jones 1992). The main and most direct role usually attributed to HS is associated to its use as primary source 
energy by heterotrophic microorganisms, tying its use directly to the microbial loop (Azam et al. 1983, Farjalla et al. 2009). Additionally, there are evidences that HS are absorbed by organisms and interact with cell's biochemical components and its signaling mechanisms (Steinberg et al. 2008a, Suhett et al. 2011).

Aquatic environments with high HS concentrations are identified as a distinct and specific class, easily recognized by its dark color (blackwater/brownwater), low productivity, $\mathrm{pH}$, light penetration and dissolved oxygen concentration (Hessen \& Tranvik 2013). Blackwater environments can be found in the Northern region of Rio de Janeiro State (Brazil). In some of these natural lakes and ponds the concentration of dissolved organic carbon may reach $200 \mathrm{mg} \mathrm{L}^{-1}$, thus being considered highly humic environments (Farjalla et al. 2009, Suhett et al. 2004). These humic and non-humic environments are characterized as small and medium wetlands (Ramsar 2018, Bozelli et al. 2018), and harvest an immense biodiversity, acting as nursery and refuge to endemic and threatened species (Scheffer et al. 2006). Paradoxically, although the importance of these areas is recognized, they are usually vulnerable to anthropogenic impacts. In addition, the structure and functioning of these ecosystems are still not entirely understood, especially concerning the food web dynamics and the influence of HS on the composition, abundance, biomass and diversity of organisms.

The humification process by which those substances are produced (that also involves organisms' death) is quantitatively the second most important existent biogeochemical process - after photosynthesis - and it assures the stability in energy and matter cycling (Steinberg 2003). Regarding HS dynamics it is highly necessary to recognize the role of organisms, especially plankton communities, since they are important components of aquatic food webs.

Structure and function of aquatic ecosystems may respond to HS in different ways: (i) causing changes in the physical and chemical parameters and, hence, altering the primary autotrophic production and its related food web, (ii) acting as a direct source of organic carbon and energy for the food web (Jones 1992) and, (iii) more specifically, interfering in the composition, biomass and abundance of planktonic communities (phytoplankton and zooplankton), as a result of the dominance of heterotrophic processes (Steinberg 2003).

In particular, the zooplankton community is usually considered a good indicator of environmental changes and has a crucial role in the energy flow and matter cycling of aquatic environments (Sousa \& ElmoorLoureiro 2008). Many studies have pointed out the potential of zooplankton as bioindicators of trophic status and marine influences (e.g. Attayde \& Bozelli 1998, Branco et al. 2002). In a general view, however, there are few studies which correlate the variation in the structure of the zooplankton and the concentration of HS. Most studies present, either argue that zooplankton biomass and abundance decreases respond to the limitation of primary producers in blackwater environments, or either directly associate zooplankton biomass and density to the increase of total organic carbon and water color (Sarvala \& Halsinaho 1990, Kelly et al. 2016, amongst others). But fewer, directly search for the consequences of the presence of HS for the zooplankton community, relating richness, diversity and biomass to the concentration of these stressors (Sarvala et al. 1999).

Thus, the objective of our study was to verify zooplankton community's structure responses along a natural HS gradient in coastal environments of Rio de Janeiro State, also trying 
to identify possible zooplankton species that can be used as bioindicators of the presence of such substances. Altogether, this study aims to discuss whether the zooplankton community responds directly or indirectly to the increase of $\mathrm{HS}^{\prime}$ concentration in a specific time point. This single time point was used in order to attenuate the effect of temporally driven physical and chemical factors. In this preliminary research we tried to take first steps towards an understanding on the relation between zooplankton structure and high concentrations of HS in tropical aquatic ecosystems. We hypothesize that due to the stressing traits of HS (both direct - oxidative stress, and indirect - light attenuation, causing photosynthesis limitation) on zooplankton, both abundance and species diversity will be higher in ecosystems with lower values of HS concentrations. And, since that in HS rich ecosystems lowest zooplankton biomass are expected - due to the presence of smaller zooplankton groups feeding on bacteria and other heterotrophic microorganisms - we also hypothesize that zooplankton community structure will be different among the studied gradient.

\section{Study area}

Seven environments of Northern Rio de Janeiro State (Rio de Janeiro, Brazil) were studied and comprised in a HS gradient. Such environments are encompassed between $22^{\circ} 17^{\prime} 58.77^{\prime \prime} \mathrm{S} / 41^{\circ} 41^{\prime} 58.05^{\prime \prime} \mathrm{W}$ and $22^{\circ} 8^{\prime} 4.24^{\prime \prime} \mathrm{S} /$ $41^{\circ} 12^{\prime} 1.78^{\prime \prime} \mathrm{W}$ (figure 1) and are part of the Parque Nacional da Restinga de Jurubatiba, Brazil's first National Park to comprise exclusively the sandy coastal plain ('restinga') ecosystem. This region has circa. 14860 ha and an extension of $44 \mathrm{~km}$ along the coast and it is characterized by a humid tropical climate with little water deficit year out (figure 1).

The seven ecosystems chosen to represent the humic gradient are mostly formed by the transgression of sea water level which forms a set of lakes and ponds both temporary and permanent, except the most humic environment which is an upwelling of the underground watershed. This region's humic environments

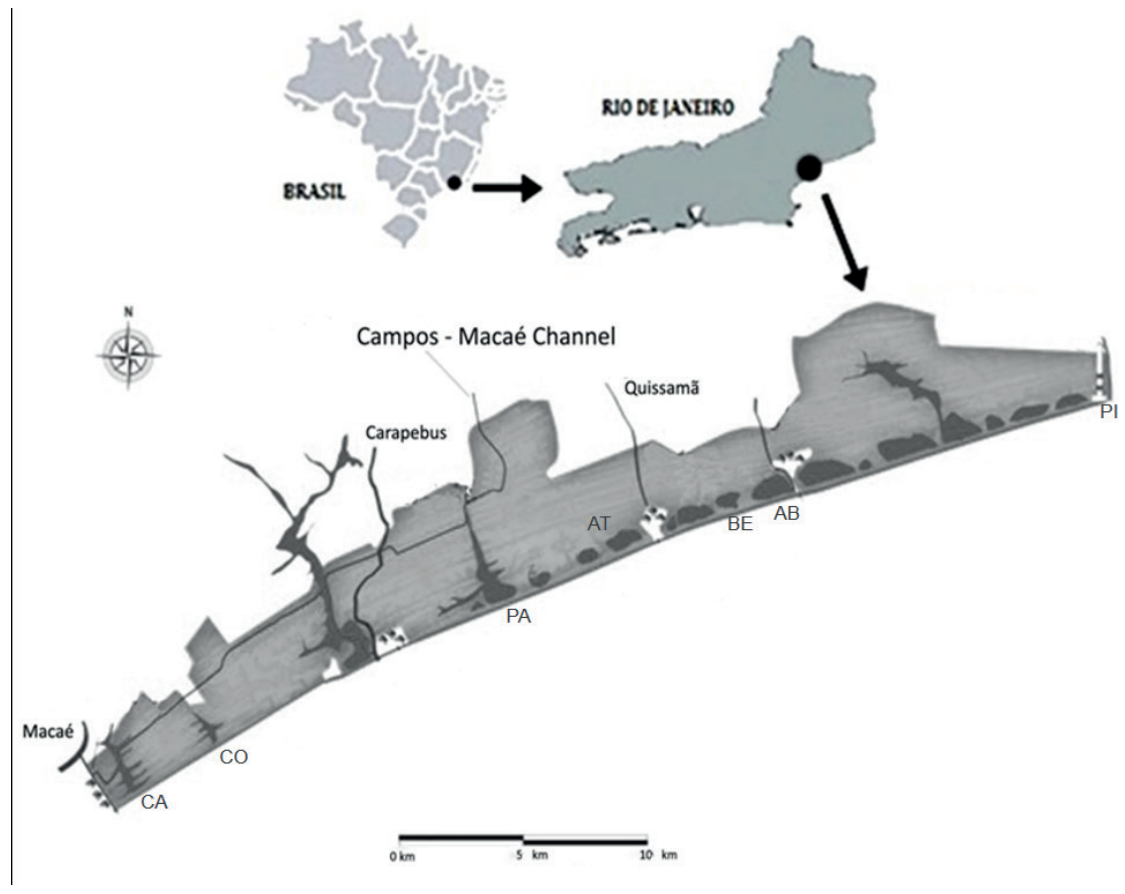

Figure 1. Representative map of the location of sampling environments studied along the humic gradient. $\mathrm{CA}=$ Cabiúnas; $\mathrm{PA}=$ Paulista; $\mathrm{PI}=$ Pitanga; $\mathrm{BE}=$ Bezerra; $\mathrm{CO}=$ Comprida; $\mathrm{AB}=$ Amarra-Boi and $A T=$ Atoleiro. Image modified from: Renault, V. 
are mostly oriented orthogonally to the coast, have low salt concentrations and are highly influenced by the mosaic surrounding 'restinga' vegetation (Farjalla et al. 2009).

The environments are named (in an increasing HS concentration order): Cabiúnas (CA), Paulista (PA), Pitanga (PI), Bezerra (BE), Comprida (CO), Amarra-Boi ( $A B$ ) and Atoleiro (AT) - figure 1. It is important to highlight that all of the sampled environments are oligomesotrophic environments of different size and morphometry but all are shallow with pelagic and littoral regions. Once again it should be noted the peculiarity of the most humic ecosystem (AT) which is a small shallow environment with highly black-colored water. The first water analysis made in AT revealed that, as similar ponds formed by the upwelling of groundwater, it had the highest dissolved organic carbon concentrations ever recorded (Steinberg et al. 2006, Farjalla et al. 2009).

\section{MATERIALS AND METHODS}

\section{Sampling}

Samples were taken during two days on February 2012. A single sampling was chosen in order to isolate the chemical effects of humic substances in the zooplankton community of each environment, ruling out seasonal preponderant effects. Water surface temperature $\left({ }^{\circ} \mathrm{C}\right)$, electrical conductivity $\left(\mu \mathrm{S} \mathrm{cm}^{-2}\right)$ and salinity were measured in situ using an YSI-30 Thermistor probe and dissolved oxygen concentrations were measured with an Oxygen meter YSI 550a. pH values were obtained immediately after arrival in the laboratory using a bench top $\mathrm{pH}$ meter.

Water samples were taken to determine total concentration of: total nitrogen $\left(\mathrm{mM} \mathrm{L}^{-1}\right)$, phosphorus $\left(\mu \mathrm{M} \mathrm{L}^{-1}\right)$, dissolved organic carbon (mg L $\mathrm{L}^{-1}$ ) analyses, chlorophyll a ( $\left.\mu \mathrm{g} \mathrm{L}^{-1}\right)$ and color. Total nitrogen was determined using a carbon and nitrogen analyzer (Shimadzu TOC-L) after digestion as proposed by Mackereth et al. (1978). Total phosphorus was determined after digestion using a Cary- Eclipse 50 Bio spectrophotometer adjusted to 882nm wavelength, as proposed by Mackereth et al. (1978). The dissolved organic carbon (DOC) was determined after water filtration on GF/F filters and sample analysis in TOC-L analyzer.

Chlorophyll a and watercolor were determined after filtration on GF/F Whatman filters. For chlorophyll a filters extracts were analyzed according to Nusch \& Palme (1975) methodology. Watercolor was determined through spectrophotometer readings on $430 \mathrm{~nm}$ wavelength and measured in absorption units (a.u). Physical and chemical variables (temperature, dissolved oxygen, total nitrogen and phosphorous, salinity, conductivity, $\mathrm{pH}$, watercolor and total DOC) were sampled in all environments 7 days prior to the community sampling. The a priori variable checking was to ensure that the environment in which the zooplankton community was living in did not suffer considerable variations in physical and chemical parameters within short time.

For the study of the zooplankton community, qualitative and quantitative samples were taken through $100 \mathrm{~L}$ of water filtration in a $50 \mu \mathrm{m}$ plankton mesh in each of the HS' gradient environments. A $50 \mu \mathrm{m}$ plankton mesh enables a homogeneous sampling of zooplankton organisms' body size, encompassing the smallest metazoan zooplankton (rotifers), nauplii and small cladocerans and larger meso/macro zooplankton as copepods and larger cladocerans. Bulk integrated water column samples were obtained with an electric pump with a known water flow. Those samples were taken in both pelagic and littoral regions of each lake and homogenized prior to filtration. Zooplankton samples were fixed in formaldehyde (4\%). 


\section{Data analyses}

Qualitative analyses of zooplankton were performed under an optical microscope integrated to microphotograph equipment used to optimize species recognition. Taxa identification were made usingtaxonomicstudies performed by Koste (1978), Nogrady et al. (1993), Fernando (2002) and Segers (2007). Quantitative samples were counted in a Sedgewick-Rafter counting cell. Species richness, abundance, diversity $\left(H^{\prime}\right)$ and evenness $\left(J^{\prime}\right)$ were calculated using the Shannon index - natural log - and Pielou index (Pielou 1969). For the diversity and evenness calculations, juvenile and nauplii forms of microcrustaceans were excluded.

Zooplankton biomass was estimated through the conversion of dry weight into carbon biomass as proposed by Ruttner-Kolisko (1977). Using a micrometric eyepiece, at least 20 individuals of each taxa were measured to determine their biovolumes (rotifers and copepods nauplii) and size-weight regressions (cladocerans and copepods). Microcrustaceans were sorted according to their development phases, rinsed with distilled water, measured and weighted (after heat drying at $60^{\circ} \mathrm{C}$ during $24 \mathrm{~h}$ ) in small pre-weighted aluminum boat, except for copepods nauplii, where biomass was obtained through biovolume estimates by length measurements. Testate amoeba biovolume and biomass conversion was also estimated based on body size (radius) measurement (Aoki et al. 2007).

To evaluate which abiotic factor contributed mostly with zooplankton species variation a Spearman correlation test was run using Hminsk package for R (R Core Team 2013).

A Canonical Correspondence Analysis (CCA) was conducted with the seven sites to depict environmental gradients (especially the humic gradient) and directly relate such gradients to zooplankton patterns of occurrence and abundance. Biotic data were log transformed $(\log x+1)$ to satisfy a normality fitting and standardized. Abiotic variables, however, were selected after the analyses of a correlation matrix. Self-correlated variables were removed from the canonical analysis. CCA was executed using $R$ software and the library used was Vegan (v. 2.0-1, compiled in $R$ version 2.13.2). The significance of each of the factorial axis was analyzed by an ANOVA test ( $p<0.05$ was considered statistically significant results).

\section{RESULTS}

\section{Water column characterization}

The humic gradient was represented mainly by a dissolved organic carbon and watercolor gradient in the sampled environments (Supplementary Material - Appendix A - Figure S1). Mean values of these two variables were higher in Atoleiro (202.55 $\mathrm{mg} \mathrm{L}^{-1}$ and 0.6390), followed by AB, CO, BE, $\mathrm{PI}$ and PA, and lower in CA (17.18 $\mathrm{m} \mathrm{L}^{-1}$ and 0.078), as shown in Table I. This table also shows that that was only a subtle variation in physical and chemical parameters measured in the field in a seven-day interval, illustrating the constancy of water column conditions for zooplankton. The linear regression performed $\left(r^{2}=0.0899\right.$ and $p<0.0001)$ shows the positive correlation between these two variables. $\mathrm{pH}$ values, on the other hand, varied indirectly related to the increase of humic substances' concentration. Lowest values of $\mathrm{pH}$ were correlated (coef. Corr $=-0.88 ; p<0.05)$ to environments where DOC (hence HS) concentrations were higher (Table I).

The lowest depth was measured in PI lagoon $(0.3 \mathrm{~m})$ and highest values of this variable were measured in both CA and CO lagoons (1.5m). Mean electrical conductivity values were higher in AT $\left(352.4 \mu \mathrm{S} \mathrm{cm} \mathrm{cm}^{-2}\right)$ and $\mathrm{BE}\left(348.7 \mu \mathrm{S} \mathrm{cm} \mathrm{cm}^{-2}\right)$, and lower in PA $\left(181.2 \mu \mathrm{S} \mathrm{cm}^{-2}\right)$ and $\mathrm{CO}\left(115.6 \mu \mathrm{S} \mathrm{cm}^{-}\right.$ $\left.{ }^{2}\right)$. Overall, salinity values ranged from 0.1 to 1.8 
Table I. Physical and chemical parameters measured in all sampled environments along the proposed humic substances gradient. Range of variation of physical and chemical variables obtained in the field between actual sampling and 7 days prior to actual sampling is portrayed for $\mathrm{DOC}$, Color, $\mathrm{pH}$, Temp, Depth, Conduc, Salinity and DO. $\mathrm{CA}=$ Cabiúnas; $\mathrm{PA}=$ Paulista; $\mathrm{PI}=\mathrm{Pitanga} ; \mathrm{BE}=$ Bezerra; $\mathrm{CO}=$ Comprida; $\mathrm{AB}=\mathrm{Amarra}-\mathrm{boi}, \mathrm{AT}=\mathrm{Atoleiro} ; \mathrm{DOC}=$ dissolved organic carbon; Color= water color; Temp = water temperature; Conduct = conductivity; $\mathrm{DO}=$ dissolved oxygen; $\mathrm{TN}=$ total nitrogen; $\mathrm{TP}$ = total phosphorous, and $\mathrm{CHL}-\mathrm{a}=$ chlorophyll biomass.

\begin{tabular}{|c|c|c|c|c|c|c|c|c|c|c|c|}
\hline & $\begin{array}{c}\text { DOC } \\
\left(\mathrm{mg} \mathrm{L}^{-1}\right)\end{array}$ & $\begin{array}{l}\text { Color } \\
\text { (u.a) }\end{array}$ & pH & $\begin{array}{c}\text { Temp } \\
\left({ }^{\circ} \mathrm{C}\right)\end{array}$ & $\begin{array}{c}\text { Depth } \\
\text { (m) }\end{array}$ & $\begin{array}{l}\text { Conduc } \\
\left(\mu \mathrm{S} . \mathrm{cm}^{-1}\right)\end{array}$ & Salinity & $\underset{\left(\mathrm{mg} \mathrm{L}^{-1}\right)}{\mathrm{DO}}$ & $\begin{array}{c}\mathrm{TN} \\
\left(\mu \mathrm{M} \mathrm{L}^{-1}\right)\end{array}$ & $\begin{array}{c}\mathrm{TP} \\
\left(\mu \mathrm{M} \mathrm{L^{-1 } )}\right.\end{array}$ & $\begin{array}{l}\text { Chl-a } \\
\left(\mu g \mathrm{~L}^{-1}\right)\end{array}$ \\
\hline CA & $\begin{array}{c}17.2- \\
24.9\end{array}$ & $\begin{array}{c}0.081- \\
0.082\end{array}$ & $\begin{array}{c}6.33- \\
6.65\end{array}$ & $\begin{array}{c}26.9- \\
27.1\end{array}$ & 1.5 & $\begin{array}{c}285.9- \\
296.4\end{array}$ & 0.1 & $\begin{array}{c}1.54- \\
5.19\end{array}$ & 3.14 & 0.25 & 1.88 \\
\hline PA & $\begin{array}{c}33.5- \\
40.1\end{array}$ & $\begin{array}{c}0.118- \\
0.121\end{array}$ & $\begin{array}{c}6.65- \\
6.72\end{array}$ & $\begin{array}{c}29.3- \\
28.8\end{array}$ & 1.3 & $\begin{array}{c}181.2- \\
152.9\end{array}$ & 0.4 & $\begin{array}{l}5.35- \\
5.86\end{array}$ & 2.93 & 0.15 & 0.32 \\
\hline PI & $\begin{array}{c}50.7- \\
57.1\end{array}$ & $\begin{array}{c}0.247- \\
0.338\end{array}$ & $\begin{array}{c}6.53- \\
6.75\end{array}$ & $\begin{array}{c}26.0- \\
26.5\end{array}$ & 0.3 & $\begin{array}{c}251.0- \\
262.5\end{array}$ & 1.5 & $\begin{array}{c}5.14- \\
5.92\end{array}$ & 7.12 & 1.31 & 11.02 \\
\hline BE & $\begin{array}{c}72.0- \\
82.5\end{array}$ & $\begin{array}{c}0.247- \\
0.295\end{array}$ & $\begin{array}{c}5.75- \\
6.06\end{array}$ & $\begin{array}{c}27.3- \\
28.5\end{array}$ & 1.0 & $\begin{array}{c}348.7- \\
368.4\end{array}$ & 1.8 & $\begin{array}{c}5.68- \\
5.87\end{array}$ & 5.85 & 0.26 & 15.04 \\
\hline CO & $\begin{array}{c}82.7- \\
94.7\end{array}$ & $\begin{array}{c}0.295- \\
0.338\end{array}$ & $\begin{array}{c}3.88- \\
4.08\end{array}$ & $\begin{array}{c}27.6- \\
28.8\end{array}$ & 1.5 & $\begin{array}{c}114.5- \\
115.6\end{array}$ & 0.1 & $\begin{array}{c}3.28- \\
4.77\end{array}$ & 7.12 & 0.21 & 1.60 \\
\hline$A B$ & $\begin{array}{l}139.0- \\
194.0\end{array}$ & $\begin{array}{c}0.465- \\
0.466\end{array}$ & $\begin{array}{c}3.47- \\
3.50\end{array}$ & $\begin{array}{c}27.5- \\
28.6\end{array}$ & 0.9 & $\begin{array}{l}219.1- \\
224.8\end{array}$ & 0.1 & $\begin{array}{l}5.07- \\
5.46\end{array}$ & 6.40 & 0.18 & 2.61 \\
\hline AT & $\begin{array}{c}197.3- \\
207.8\end{array}$ & $\begin{array}{c}0.638- \\
0.639\end{array}$ & $\begin{array}{l}3.17- \\
3.17\end{array}$ & $\begin{array}{c}24.9- \\
25.4\end{array}$ & 1.1 & $\begin{array}{c}314.3- \\
352.4\end{array}$ & 0.2 & $\begin{array}{c}0.91- \\
2.18\end{array}$ & 5.15 & 0.36 & 0.51 \\
\hline
\end{tabular}

- with the highest value occurring in BE lagoon (Table I).

Dissolved oxygen values ranged among environmentsfrom 0.91 to $5.92 \mathrm{mgL}^{-1}$. Lowestmeans were measured in the most humic environment (AT) and the highest in an intermediate level of humic substances concentration (BE). However, one of the lowest values observed was obtained in CA, which is one of the environments with low HS concentrations in the gradient analyzed.

Total nutrients values showed variations of total phosphorous and nitrogen in all environments sampled. Total nitrogen had higher values in $\mathrm{CO}$ and $\mathrm{PI}\left(7.12 \mu \mathrm{M} \mathrm{L}^{-1}\right)$ and lower in $\mathrm{PA}\left(2.93 \mu \mathrm{M} \mathrm{L}^{-1}\right)$. On the other hand, total phosphorous concentration ranged from 0.15 to $1.31 \mu \mathrm{M} \mathrm{L}^{-1}$, and its lowest value was also found in PA $\left(2.93 \mu \mathrm{M} \mathrm{L}^{-1}\right)$. In the simulated humic gradient, total phosphorous and nitrogen showed no correlated variation, and, specially, total nitrogen values varied very little, while compared to other chemical parameters.

As for chlorophyll-a values, the variation observed ranged from 0.32 to $15.04 \mu \mathrm{g} \mathrm{L}^{-1}$. Lower values were observed in both AT (most humic environment) and PA (the second least humic environment). Intermediate HS concentration environment, BE, had the highest chlorophyll-a concentration measured in this study. No significant correlation was found between total chlorophyll-a values and color ( $p>0.05)$.

\section{Zooplankton community structure}

73 zooplankton taxa were identified (table II), common from littoral, pelagic and benthonic areas. Organisms were acknowledged as belonging to four taxonomic groups: Rotifers, cladocerans, copepods and protozoans. 27 
Table II. Zooplankton species inventory in all analyzed environments. $\mathrm{CA}=$ Cabiúnas; $\mathrm{PA}=\mathrm{Paulista;} \mathrm{PI}=\mathrm{Pitanga}$;E=

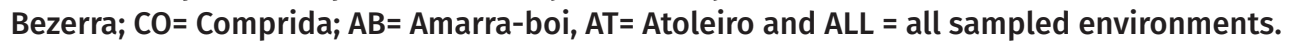

\begin{tabular}{|c|c|}
\hline Rotifera & Cladocera (Cont.) \\
\hline Ascomorpha ecaudis Perty, $1850^{\text {CA, co }}$ & Diaphanosoma brevireme Sars, $1901^{\mathrm{CA}, \mathrm{AB}, \mathrm{AT}}$ \\
\hline Ascomorpha saltans Bartsch, $1870^{\text {CA }}$ & Diaphanosoma spinulosum Herbst, $1975^{\text {CA, PA }}$ \\
\hline Asplanchna sieboldii Leydig, $1854^{\text {CA }}$ & Disparalona leptorhyncha Smirnov, $1996^{\mathrm{PA}}$ \\
\hline Bdeloidea Hudson, $1884^{\text {CA, PA,BE, AB,AT }}$ & Dunhevedia odontoplax Sars, $1901^{\mathrm{AB}}$ \\
\hline Brachionus plicatilis Müller, $1786^{\mathrm{BE}}$ & Ephemeroporus barroisi Richard, $1894^{\mathrm{BE}, \mathrm{CO}}$ \\
\hline Collotheca ornata Ehrenberg, $1830^{\mathrm{Pl}, \mathrm{BE}}$ & Ephemeroporus hybridus Daday, $1905^{\mathrm{co}}$ \\
\hline Conochilus coenobasis Skorikov, $1914^{\text {CA }}$ & Ilyocryptus spinifer Herrick, $1882^{\text {co }}$ \\
\hline Hexarthra intermedia Hauer, $1953^{\text {CA, PA, PI, BE }}$ & Leberis davidi Richard, $1895^{\mathrm{CO}, \mathrm{AB}}$ \\
\hline Hexarthra mira Hudson, $1871^{\text {CA, Pl }}$ & Macrothrix laticornis Jurine, $1820^{\mathrm{AB}}$ \\
\hline Kellicottia bostoniensis cf. Rousselet, $1908^{\text {AT }}$ & Macrothrix paulensis G. O. Sars, $1900^{\mathrm{Pl}}$ \\
\hline Lecane boettgeri Koste, $1986^{\mathrm{AB}}$ & Moina minuta Hansen, $1899^{\mathrm{PA}, \mathrm{PI}}$ \\
\hline Lecane bulla Gosse, $1851^{\mathrm{CA}, \mathrm{BE}, \mathrm{CO}, \mathrm{AT}}$ & Scapholeberis armata Herrick and Turner, $1895^{\text {AT }}$ \\
\hline Lecane curvicornis Murray, $1913^{\mathrm{AB}}$ & Simocephalus latirostris Stingelin, $1906^{\text {CA }}$ \\
\hline \multicolumn{2}{|l|}{ Lecane leontina Turner, $1892^{\text {CA, PA, CO,AB, AT }}$} \\
\hline Lecane luna Müller, $1776^{\mathrm{AB}}$ & Copepoda \\
\hline Lecane lunaris Ehrenberg, $1832^{\mathrm{CA}, \mathrm{PA}, \mathrm{BE}, \mathrm{CO}, \mathrm{AB}}$ & Calanoid juvenile ${ }^{\mathrm{CA}, \mathrm{PA}, \mathrm{CO}, \mathrm{AB}, \mathrm{AT}}$ \\
\hline Lecane signifera Jennings, $1896^{\mathrm{CA}, \mathrm{CO}, \mathrm{AB}, \mathrm{AT}}$ & Calanoid nauplii ${ }^{\text {PA,AB,AT }}$ \\
\hline Monommata dentata Wulfert, $1940^{\mathrm{AB}}$ & Cyclopoid juvenile ALL \\
\hline Plationus patulus Müller, $1786^{\text {CA }}$ & Cyclopoid nauplii ${ }^{\text {ALL }}$ \\
\hline Polyarthra dolichoptera Idelson, $1925^{\text {CA, Pl }}$ & Diaptomus azureus Reid, $1945^{\text {CA,AB,AT }}$ \\
\hline Sinantherina sp. Bory de St. Vincent, $1826^{\mathrm{CA}}$ & Harpaticoid juvenile ${ }^{\mathrm{PA}, \mathrm{P}, \mathrm{BE}}$ \\
\hline Synchaeta sp. Ehrenberg, $1832^{\mathrm{BE}}$ & Harpaticoid nauplii ${ }^{\mathrm{PA}, \mathrm{PI}}$ \\
\hline Synchaeta tremula Müller, $1786^{\text {Pl }}$ & Harpaticoid ${ }^{\text {PA,PI }}$ \\
\hline Testudinella ohlei Koste, $1972^{\mathrm{co}}$ & Mesocyclops longisetus Thiébaud, $1912^{\text {CA }}$ \\
\hline Testudinella patina Hermann, $1783^{\text {CO AB, AT }}$ & Microcyclops anceps Richard, $1897^{\text {AT }}$ \\
\hline Trichocerca pusilla Jennings, $1903^{\mathrm{Pl}}$ & Microcyclops sp. Claus, $1893^{\text {CA }}$ \\
\hline \multirow{2}{*}{ Trichocerca sp. Lamarck, $1801^{\text {AT }}$} & Notodiaptomus cearensis Wright S., $1936^{\mathrm{PA}, \mathrm{CO}}$ \\
\hline & Notodiaptomus sp. Kiefer, $1936^{\text {CA,PA }}$ \\
\hline \multicolumn{2}{|l|}{ Cladocera } \\
\hline Alona dentifera Sars, $1901^{\mathrm{AB}, \mathrm{AT}}$ & Protozoa \\
\hline Alona glabra Sars, $1901^{\mathrm{AB}}$ & Arcella discoides Ehrenberg, $1843^{\mathrm{AB}, \mathrm{AT}}$ \\
\hline Alonella clathratula Sars, $1896^{\mathrm{CO}, \mathrm{AB}, \mathrm{AT}}$ & Arcella megastoma Penard, $1902^{\mathrm{AB}}$ \\
\hline Anthalona verrucosa Sars, $1901^{\mathrm{BE}}$ & Centropyxis aculeata Ehrenberg, $1838^{\mathrm{PA}, \mathrm{BE}, \mathrm{CO}, \mathrm{AB}, \mathrm{AT}}$ \\
\hline Bosmina hagmanni Stingelin, $1904^{\text {CA }}$ & Centropyxis discoides Penard, $1902^{\mathrm{BE}, \mathrm{CO}, \mathrm{AT}}$ \\
\hline Bosminopsis deitersi Richard, $1895^{\text {CA,PA,CO,AB,AT }}$ & Colonial ciliate ${ }^{\mathrm{CA}}$ \\
\hline Ceriodaphnia cornuta Sars, $1885^{\text {CA, PA,AT }}$ & Difflugia corona Wallich, $1864^{\text {CA,Pl,CO }}$ \\
\hline Chydorus sp. Leach, $1843^{\text {CA }}$ & Difflugia pseudogramen Gauthier-Livere \& Thomas $1960^{\text {CA,PIT,CO,AB }}$ \\
\hline Chydorus sphaericus O. F. Müller, $1776^{\mathrm{PA}, \mathrm{co}}$ & Euglipha sp. Dujardin, $1841^{\text {AT }}$ \\
\hline Coronatella poppei Richard, $1897^{\mathrm{AB}}$ & Protocurcubitella coroniformis Gauthier-Lièvre \& Thomas, 1960 BE \\
\hline Diaphanosoma birgei Korinek, $1981^{\text {CA,PA }}$ & \\
\hline
\end{tabular}


rotifers species, 24 cladocerans, 6 copepods (juveniles and nauplii forms of three distinct orders not included) and 9 protozoans, (especially testate amoebas) were identified. From these, 28 species were encountered on only one occasion, or sampled environment, such as: Brachionus plicatilis, Asplanchna sieboldi, Bosmina hagmanni, Ilyocryptus spinifer, Scapholeberis armata, Microcyclops anceps, Arcella megastoma, amongst others. Other individuals occurred in more than one environment, though only cyclopoid copepods' juveniles and nauplii had $100 \%$ of occurrence frequency.

Total zooplankton abundance ranged from 3800 ind $\mathrm{m}^{-3}$ in BE to 84970 ind $\mathrm{m}^{-3}$ in PE (figure 2). It is important to point out that the smallest abundances were observed in environments with intermediate to high humic substances concentration, On the other hand, highest densities were found in PI, PA and CA, which have lowest DOC concentration. Overall, there was a decrease on total abundance of the zooplankton community while the HS gradient increased.

Relative abundance (figure 2), in turn, showed higher densities of testate amoeba (protozoans) in environments with high concentrations of humic substances. Cladocerans were more abundant in PA lagoon, and its highest abundances were found in environments with lower HS concentrations. In $\mathrm{PI}$, about $60 \%$ of all abundance was represented by rotifers. copepods were frequent in all sampled environments, but smallest abundance of this group was observed in AT and PI.

As to taxa dominance in each group, it is important to highlight the predominance of copepods' juveniles and nauplii in all of the studied environments. Rotifers were mostly represented by Lecane leontina (in AT and AB), Lecane bulla (in AT) and Hexarthra intermedia (in PI and PA). And in Cabiúnas lagoon, rotifers abundance was dominated by: Polyarthra dolichoptera, Conochilus coenobasis and Asplanchna sieboldi. The rotifer Brachionus

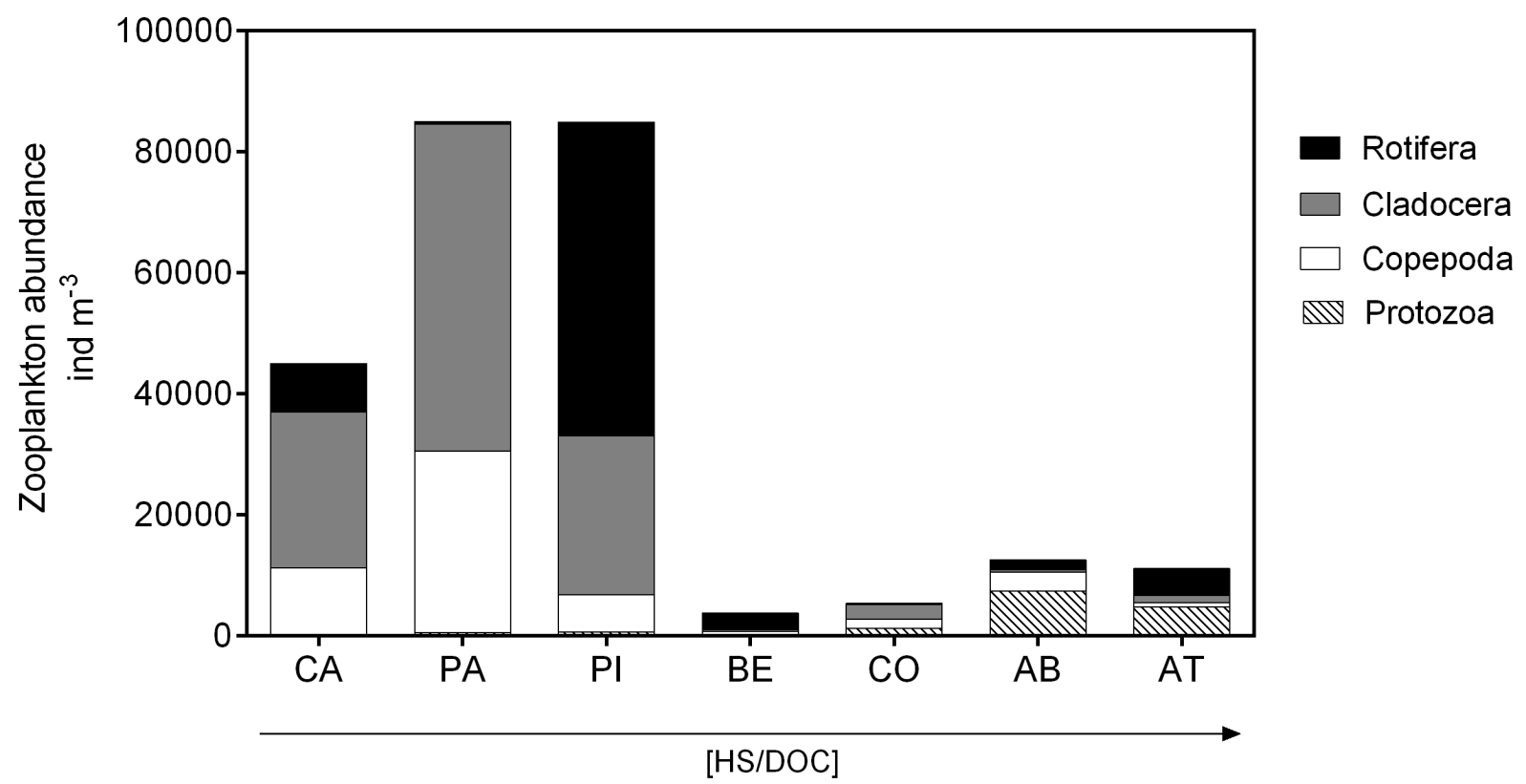

Figure 2. Zooplankton abundance (ind $\mathrm{m}^{-3}$ ) in all of the sampled environments along the studied HS gradient. $\mathrm{CA}=$ Cabiúnas; $\mathrm{PA}=$ Paulista; $\mathrm{PI}=\mathrm{Pitanga} \mathrm{BE}=$ Bezerra; $\mathrm{CO}=$ Comprida; $\mathrm{AB}=$ Amarra-Boi; $\mathrm{AT}=$ Atoleiro. 
plicatilis was only observed in $\mathrm{BE}$, in very high densities.

Overall, cladocerans were primarily represented by Bosminopsis deitersi, Ceriodaphnia cornuta, Diaphanosoma spinulosum, Diaphanosoma birgei, and Moina minuta. In AT, which is the highly humic environment, the cladoceran Scapholeberis armata had a restricted occurrence and high abundance. Testate amoebas that had the highest densities were: Centropyxis aculeata, Centropyxis discoides and Arcella discoides.

As to species richness, the highest value was observed in CA, with a total of 29 recognized species (Figure 3a). Environments with lower species richness were BE (13) and PI (11). All humic environments had intermediate species richness values: AB (22), AT (19) and CO (17). Rotifers was the group with the higher species richness in four of the seven environments studied. PA, CO and AT showed cladocerans as the dominant species richness group (Figure 3a).

Species diversity (figure $3 \mathrm{~b}$ ) showed a pattern in relation to the humic gradient. It can be observed that lower values of $\alpha$ - diversity were registered in intermediate humic concentrations (PI and BE). In these environments, both diversity and evenness had low values when compared to the other environments along the

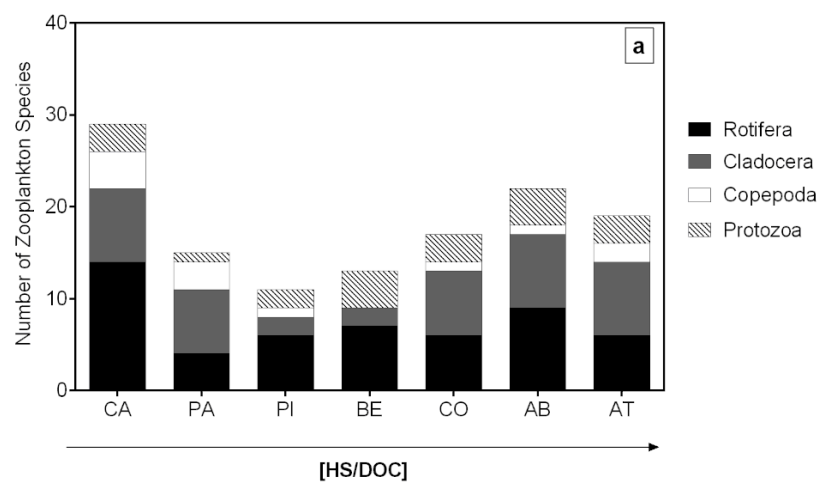

humic gradient. Higher values of such variables, however, were observed in environments with high concentration of HS - AT, AB and C.

Nonetheless, biomass values, expressed

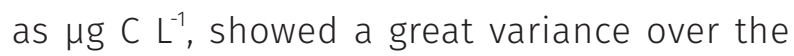
studied gradient. Highest biomass values were found in less humic environments, in essence as also shown by variations in total abundance (figure 4). More specifically, the highest biomass value encountered was in PA $\left(560.42 \mu \mathrm{g} \mathrm{C} \mathrm{m}{ }^{-3}\right)$.

Lowest values of carbon content pooled in the zooplankton community were, consequently, found in humic and highly humic environments. The smallest biomass value found was in BE $\left(0.52 \mu \mathrm{g} \mathrm{C} \mathrm{m}{ }^{-3}\right)$ which had the predominance of a small rotifer (B. plicatilis) in the zooplankton composition. It was also noticeable that differences in the total biomass of each environment were closely related to the relative biomass of different and more or less abundant zooplankton groups (figure 4). Overall, cladocerans and copepods were the organisms which most contributed to biomass increase, except in $A B$, where protozoans and copepods contributed extremely to biomass increase.

Figure 3. Species richness (a) and diversity (Shannon index, $\mathrm{H}^{\prime}$ and Pielou index, $\mathrm{J}-\mathrm{b}$ ) of zooplankton groups in all of the sampled environments along an increasing humic substances gradient. $\mathrm{CA}=\mathrm{Cabiúnas;} \mathrm{PU}=\mathrm{Paulista;} \mathrm{PI}=$ Pitanga; $B E=$ Bezerra; $C O=$ Comprida; $A B=$ Amarra-Boi; $A T=$ Atoleiro. 


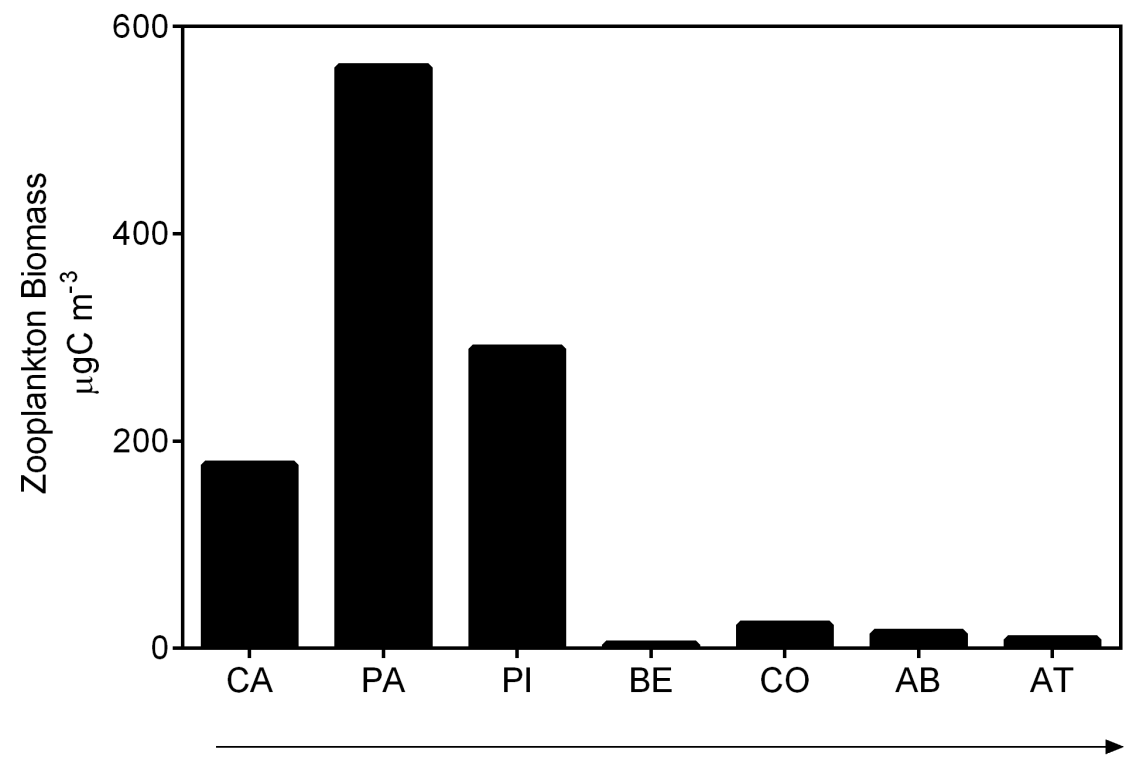

[HS/DOC]
Figure 4. Biomass variation $\left.(\mu \mathrm{gC} \mathrm{m})^{-3}\right)$ in all of the studied environments along an increasing humic substances concentration. $\mathrm{CA}=$ Cabiúnas; $\mathrm{PA}=$ Paulista; $\mathrm{PI}=$ Pitanga; $\mathrm{BE}=$ Bezerra; $\mathrm{CO}=$ Comprida; $\mathrm{AB}=$ Amarra-Boi; AT= Atoleiro.

\section{Zooplankton community structure variation along the humic gradient}

The main shaping role of humic substances to the zooplankton community was represented by the DOC and color gradient and analyzed through a Canonical Correspondence Analysis (CCA), shown in figure 5. In this CCA diagram two main and more important axes are represented. Both axes combined explained $47.7 \%$ of data variability. Meanwhile, the cumulative percentage explained by the sum of the three CCA axes was $65.4 \%$. All correlations between species abundance and environmental factors were statistically significant $(p<0.05)$, as shown by the Monte-Carlo test $(p=0.016)$. Also, eigenvalues of each axis were tested and were also statistically significant ( $p=0.001)$.

The first axis, which explained alone $26.7 \%$ of data variability, can be interpreted as the main gradient obtained in the studied environments. It is constituted by a pH and DOC gradient, since in its negative side (left) we can observe higher values of $\mathrm{pH}$ and on its opposite side (positive- right) higher values of DOC, all of each represented by vectors (figure 5). On the other hand, Axis 2 explained $21 \%$ of total data variability and was mainly representative of dissolved oxygen gradient obtained in the sampled environments. Salinity was also determinant to obtain the environmental gradient represented by axis 2 , right next to the dissolved oxygen (DO) vector, the environment represented by $B E$ had the highest value of both DO and salinity.

Next to the DOC representative vector it can be observed the disposition of the most humic environments, confirming the position of each environment in the proposed gradient. $A T, A B$ and $\mathrm{CO}$ were grouped next to this vector. On the other hand, environments groups further away from Axis 1, such as BE and CA were mostly correlated to the environmental gradient identified by axis 2 (dissolved oxygen). PI had a high negative correlation with Axis 2, being showed in the graph as the far point on the left quadrant (Figure 5).

In the disposition of each species in the ordination graph (figure 5) it is important to highlight species restricted to humic environments or highly correlated to axis 1 


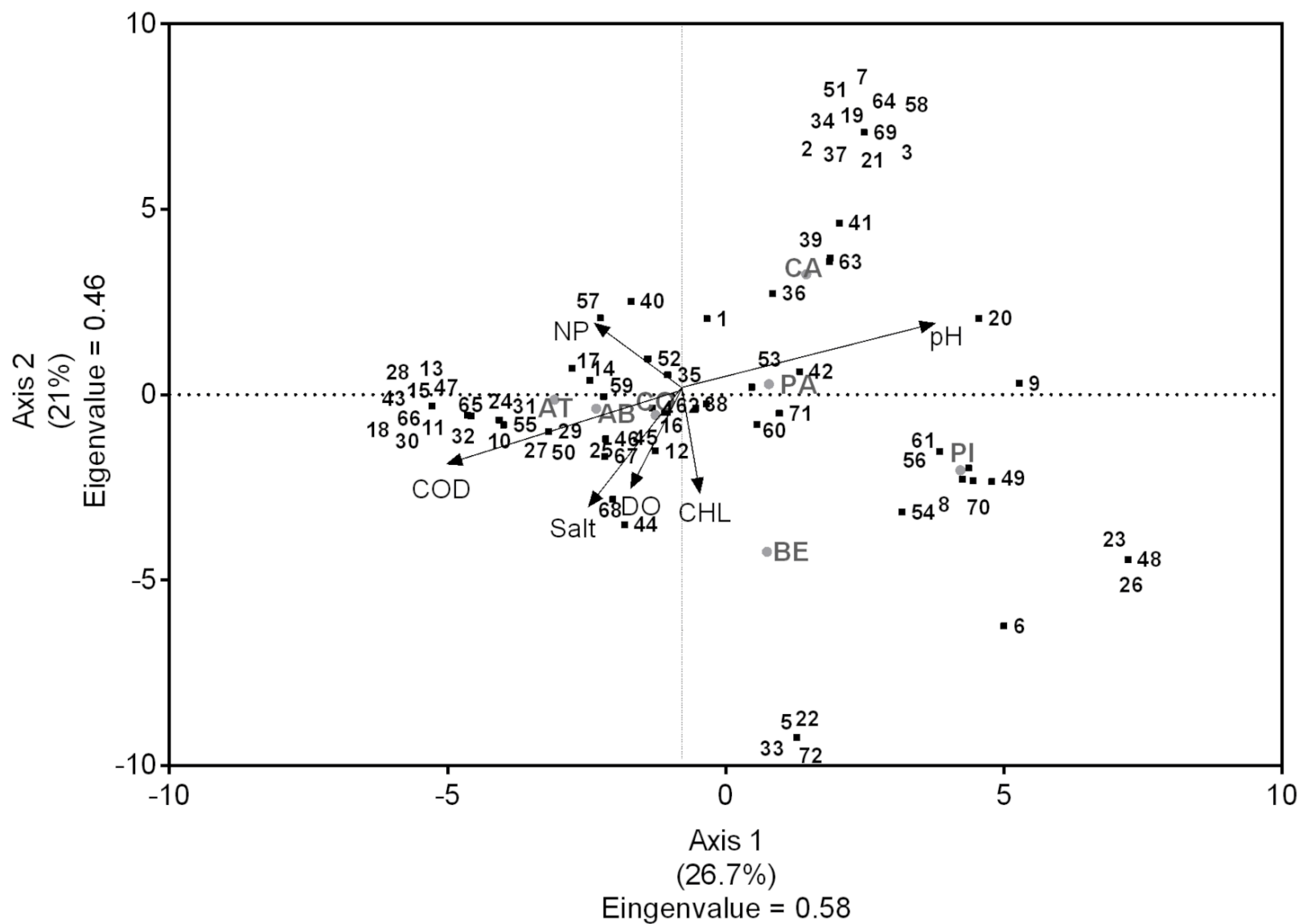

Figure 5. CCA diagram integrating abundance occurrence, physical and chemical variables, and studied environments. Letters represent environments: $A T=A$ toleiro; $A B=A m a r r a-B o i ; C O=C o m p r i d a ; B E=B e z e r r a ; P I T=$ Pitanga; $P A=$ Paulista and $C A=C$ abiúnas. Physical and chemical variables were: $\mathrm{pH} ; \mathrm{DOC}=$ dissolved organic carbon; $\mathrm{TP}=$ total phosphorous; Salt= salinity; $\mathrm{OD}=$ dissolved oxygen; and $\mathrm{CHL}=$ chlorophyll biomass. Biotic variables are represented by numbers: $1=$ Ascomorpha ecaudis; $2=$ Ascomorpha saltans; $3=$ Asplanchna sieboldi; 4= Bdeloidea; 5= Brachionus plicatilis; $6=$ Collotheca ornata; $7=$ Conochilus coenobasis; $8=$ Hexarthra intermedia; $9=$ Hexarthra mira; 10= Kellicottia sp. cf.; 11= Lecane boettgeri; 12= Lecane bulla; 13= Lecane curvicornis; 14= Lecane leontina; 15= Lecane luna; 16= Lecane lunaris; $17=$ Lecane signifera; $18=$ Monommata dentate; $19=$ Platyonus patulus; $20=$ Polyarthra dolichoptera; 21= Sinantherina sp.; 22= Synchaeta sp.; 23= Synchaeta tremula; $24=$ Testudinela patina; 25= Testudinela ohlei; $26=$ Trichocerca pusilla; $27=$ Trichocerca similis; $28=$ Alona glabra; $29=$ Leberis davidi; $30=$ Coronatella poppei; 31= Alonella clathratula; 32= Alona dentifera; 33= Anthalona verrucosa; 34= Bosmina hagmanni; 35= Bosminopsis deitersi; 36= Ceriodaphnia cornuta; 37= Chydorus sp.; 38=Chydorus sphaericus; 39= Diaphanosoma birgei; 40= Diaphanosoma brevireme; 41= Diaphanosoma spinulosum; 42= Disparalona leptorhynca; 43= Dunhevedia odontoplax; 44= Ephemeroporus barroisi; 45= Ephemeroporus hybridus; 46= llyocryptus spinifer; 47= Macrothrix laticornis; 48= Macrothrix paulensis; 49= Moina minuta; 50= Scapholeberis armata; 51= Simocephalus latirostris; 52= Calanoida juvenile; 53= Cyclopoid juvenile; 54= Harpacticoida juvenile; 55= Microcyclops anceps; 56= Harpaticod Copepod; 57= Diaptomus azureus; 58= Microcyclops sp.; 59= Calanoid Nauplii; $60=$ Cyclopoid Nauplii; 61= Harpacticoid Nauplii; 62= Notodiaptomus cearensis; $63=$ Notodiaptomus sp.; 64= Mesocyclops longisetus; $65=$ Arcella discoides; 66= Arcella megastoma; $67=$ Centropyxis aculeate; $68=$ Centropyxis discoides; $69=$ Colonial Ciliate; $70=$ Difflugia corona; 71= Difflugia pseudogramen; 72= Protocurcubitella coroniformis. 
such as Scapholeberis armata (also mentioned beforehand), Lecane lunaris, Alona dentifera, amongst others. Species' scores grouping around each vector or environment plot, shows the importance of the gradient represented in Axis 1 as the DOC or humic substances gradient. Thus, species grouped further to the right indicate a high correlation with increasing DOC content.

Zooplankton taxa grouping in relation to higher values of $\mathrm{pH}$ and lower values of DOC concentration illustrates the preference of these species to environments with conditions similar to CA lagoon. Species like Ascomorpha saltans (2), Hexarthra mira (9) and Polyarthra dolichoptera (20) together with microcrustaceans, such as Simocephalus latirostris, Diaphanosoma spinulosum and Microcyclops sp., could be pointed out as examples for such preference, along with every species grouped further away from the graph intercept, moreover, less correlated with the higher concentrations DOC (hence, HS).

Furthermore, in relation to Axis 2 it can be observed a group of four taxa (Brachionus plicatilis, Synchaeta sp., Anthalona verrucosa and Protocurcubitella coroniformis), related to higher values of dissolved oxygen and accordingly correlated to environment represented by BE. Another important highlight is the species grouping in the lower left quadrant (figure 5), showing a high correlation between these species abundance and the high pH, low salinity and chlorophyll content, found specially in CA environment. These species grouping was mainly represented by Asplanchna, Ascomorpha, Conochilus, Platyonus, Sinantherina, Diaphanosoma, Chydorus, Ceriodaphnia and Mesocyclops genera and calanoids nauplii and protozooplankton representatives (shown in graph as numbers: 2, 3, 7, 19, 20, 21, 36, 37, 39, 41, 51, 58, 63, 64 and 69). All additional information regarding Species Scores in the CCA are provided in the Supplementary materials (Supplementary Material - Appendix B - Table SI).

\section{DISCUSSION}

\section{Environmental variation along the humic gradient}

The humic gradient, which is mentioned here, was in fact obtained due to the variation in color and dissolved organic carbon content, since HS could represent over $95 \%$ of the DOC in most water bodies (Steinberg 2003, Suhett et al. 2011). In the freshwater ecosystems of the Restinga, DOC usually shows fluctuation between sites and seasons (Suhett et al. 2013), though prevailing the overall characterization and variation in rage of each environment.

As to the direct correlation found between DOC and water color, Klavins et al. (2003) also associated positively the presence of HS and color of several European humic lakes. In addition, the decreasing values of $\mathrm{pH}$ along the studied gradient are positively related to the increase of HS in the water column. This inverse pattern between $\mathrm{pH}$ and humic concentration was also found in landmark studies such as Nürnberg \& Shaw (1998) in comparisons performed in 600 lakes, among each were black and clear water lakes from temperate regions. In Brazil, this inverse relation is also found, for instance, in the Rio Negro drainage basin (Rocha \& Sargentini 1999, Matsuo \& Val 2002, Steinberg et al. 2007).

Another important variable to be observed here is the dissolved oxygen concentration. Its inverse variation in the presence of higher concentrations of DOC shows a possible relation between oxygen consumption rates and mineralization of HS (Cunha-Santino \& Bianchini 2004). In addition, Steinberg et al. (2006) reinters that one of the direct effects of the interaction between organisms and HS 
would be the decrease in photosynthesis rate, which might also explain the decrease of this gas concentration in the water column of humic environments.

Nutrients (total phosphorous and nitrogen), in their turn, did not show any noticeable coupling to the HS' gradient. Humic environments, specially coastal Brazilian ecosystems, are classified as carbon rich, but inorganic nutrients poor environments - which truly affects metabolic rates (plus microbial respiration) (Farjalla et al. 2009).

Chlorophyll-a variation was not widely correlated to the DOC and HS gradient. This lack of relation, however, was not expected. In humic environments, primary producers' biomass is directly affected, since photosynthesis rate is usually limited, specially due to light attenuation (HS coloring trait) and nutrients limiting bioavailability (Arvola et al. 1999). Nevertheless, recent researches have tried to elucidate contrasting results found in the study of phytoplankton communities in humic lakes. And, in opposing to what it was expected, some of these studies confirm that with the addition of HS to the water it may occur a stimulation of phytoplankton growth - due to the presence of more labile substances, caused by organic matter photo-oxidation, available for phytoplankton (Carlsson \& Tester 1995, Matveev \& Robson 2014).

\section{The zooplankton community variation along the humic gradient}

Zooplankton community's composition, abundance and biomass were influenced by the humic gradientfound in the coastal environments of Northern Rio de Janeiro State. Zooplankton abundance decreases in intermediate and high concentrations of HS, though not responding linearly to the present gradient. Other studies also found such interaction though causes for this variation might be related to changes in physical and chemical aspects of the water column, caused by the increase in DOC concentrations (Sarvala et al. 1999). Kelly et al. (2016) found opposite interactions between DOC additions and zooplankton density: the increase of zooplankton density coupled to DOC increases were mainly due rises in gross primary production and resource quality (lower C:P ratios in consumed food). Thus, an important discussion is how and which resources are obtained to maintain zooplankton populations in humic and clear water environments (Hessen \& Sharthau 1988, Kelly et al. 2014).

In this aspect, variations in dominant groups might be an indicator of resource consumption and availability. For example, cladocerans species in high DOC environments usually rely on phytoplankton with little use of either bacterial or terrestrial resources (Galloway et al. 2015). These differences in the available resource for zooplankters were most likely seen in our study: the higher abundance of protozoans, specially testate amoebae, in the most humic environments could be then explained by the predominant feeding habit of this group: their diet is generally opportunistic, feeding of microparticules, specially bacteria and algae as dominant items (Han et al. 2007). In addition, it could be observed the presence of macrophyte- associated taxa (such as Arcella discoides and Cetropyxis aculeata) (Lansac-Tôha et al. 2014) in humic-rich environments ( $A T, A B$ and $\mathrm{CO}$ ).

Hessen et al. (1990) studying a humic lake indicated that the plankton particulate organic pool was mainly represented by Acanthodiaptomus denticornis (a calanoid copepod), and the following pelagic and littoral cladocerans genera: Holopedium, Diaphanosoma, Daphnia and Bosmina. Our study, in addition to Hessen et al. (1990) findings, 
showed the presence of benthonic and littoral species whenever the humic concentration was higher. Such pattern was also observed by Klavins et al. (2003). These authors did not find any truly limnetic dominant species in humic lakes but, on the contrary, there was a higher occurrence of benthonic and littoral species (e.g. Alona guttata and Acroperus harpae), this occurrence also happened in our humic environments. Such pattern can also be related to resource acquisition and use in humic environments, and how well different species use allochthonous resources (Berggren et al. 2014) and autochthonous resources such as periphyton (Rodríguez et al. 2012, Vesterinen et al. 2016).

In terms of total abundance, however, there was a high abundance of cladocerans such as Scapholeberis armata, in humic environments, and Bosminopsis deitersi in both humic and non humic environments. B. deitersi's presence is coherent with the low values of $\mathrm{pH}$ encountered, since such organisms are acidophilic (Choueri et al. 2005). S. armata, on the contrary, is a Daphniidae that has an occurrence in the American continent (Elmoor-Loureiro 2000) and it deserves special attention: its presence was only registered in the environment with the highest humic substances concentration (AT). S. armata's presence was remarkably related to the highest values of DOC and its density was the highest between cladocerans. These individuals have the habit of remaining next to the water thread, collecting hiponestonic algae (Dumoont \& Negrea 2002) and, though they consume a large spectra of food items, they are very selective feeders (DeBiase \& Taylor 2005). S. armata individuals usually have a differentiated color in their valves: a deep brown color. Such diagnosis is common of Scapholeberis genera (Dumont \& Pensaert 1983) and could be interpreted as an adaptation to reduce predation risk by macroinvertebrates and planktivorous fish in humic environments. The term 'humic coloration' of cladocerans valves has already been used Bekker et al. (2012). In addition, Bossuyt et al. (2005) found that a species of the Scapholeberis genera, amongst other, have a considerable sensitivity to acute copper exposition, once again highlighting the bioindicator characteristic of species within this genus.

The ability to use the bacteria pool is the key to energy transfer in humic lakes and this property differs greatly between zooplankton microcrustaceans: cyclopoids copepods, for instance, use very little of the bacterioplankton carbon pool available, unlike the calanoids (Hessen \& Tranvik 1998). In our study, cyclopoids copepods (juvenile and nauplii) were more abundant in environments with lower concentrations of humic compounds, confirming the reproductive success of this Family where other food items are more present than bacteria and detritus. It is important to highlight, however, that in humic lakes the food web is partly fuelled by the abundant terrestrial carbon (Gutseit et al. 2007a, Hessen et al. 1990), though this resource is thought to be an incongruent food source, unable to sustain secondary production in lakes (Brett et al. 2009) and also having an important role in shaping resources quality for zooplankton (Nova et al. 2019).

Rotifers community structure also varied along the gradient proposed, and some particular species should be highlighted since they indicated, or preferred, one condition (high or low HS concentration) over another. Lecane boettgeri, for example, only occurred in AM (which has a high humic concentration). According to Branco et al. (2005) this species, in Brazilian territory, was only recorded in a Northern Rio de Janeiro humic lagoon, Comprida, also studied here. Another example, 
amongst others, was the presence of Polyarthra dolichoptera, present only in CA and PI, both with lower HS content. Lecane leontina had higher density in environments with higher HS concentration that might point out to a higher population reproductive success of this species in these environments. Species of this genera usually feed upon detritus and bacteria (Pourriot 1977), most abundant in humic environments. Another of Lecane species (L. quadridentata) has been widely used in sensitivity tests due to its direct toxicity reaction to chemicals in the water (Sarma et al. 2010), also illustrating that the presence of species of this genus are extremely sensitive to favorable water column conditions.

Another particularity found in rotifers assembly was the presence of Brachionus plicatilis in BE (which has intermediate HS concentration). This occurrence, however, is more related to the salinity shifts of this environment, since salinity has to be faced as a strong driver of species composition (Santangelo et al. 2014). B. plicatilis is typically found in brackish waters, though it is considered a cosmopolite and salinity tolerant species (Ortells et al. 2003). B. plicatilis is a species complex with variable morphology related to variations in DNA taxonomy, this might contribute to a wide range of forms and unresolved diversity of this group (Mills et al. 2017).

We could not observe a clear and straight relationship between total species richness and the humic gradient. However, what can be observed is higher species richness in Cabiúnas lagoon, the least humic environment. The low concentration of HS in this environment may not be completely unlinked with the understanding of the zooplankton community dynamics, specially due to the fact that HS are potentially stressors (oxidative stress) for aquatic organisms (Steinberg et al. 2010) and that communities inhabiting humic and clearwater lakes might respond differently in relation to HS/DOC presence and concentration (Robidoux et al. 2015).

Furthermore, species diversity had no direct and linear relation along the gradient, though a strong influence on species composition was observed. This fact, however, contradicts some results found in the environments along the humic gradient. Humic environments are thought to have reduced alpha-diversity when zooplankton, fish and benthonic communities are concerned (Steinberg et al. 2008b). The effects of HS over community diversity is conflicting: on one hand low diversity values are in fact observed in humic environments, on the other some humic lakes have higher diversity than oligo and mesotrophic clear water lakes (Hessen \& Tranvik 1998). Thus, the role of nutrients in shaping the communities' diversity cannot be overlooked in both humic and clear water environments. Aquatic communities' responses to nutrient loadings differ between these ecosystem's categories (Faithfull et al. 2015), causing alterations in gross net productivity and hence resource availability for zooplankters. Another important determinant of zooplankton community diversity in the studied environments is the difference in spatial heterogeneity among each sampling site. Though the sampling method applied was chosen in order to minimize the underestimation of species diversity, the surface areas between the sampled environments was different. Surface area (higher in CA, PA and CO) could also have been a driver in species diversity along the proposed gradient (Chaparro et al. 2015, Seebens et al. 2013).

Finally, the study of the zooplankton community structure and composition along a tropical natural humic substances gradient was important to shed light on the dynamics of this community when facing a strong abiotic 
chemical determinant (humic concentration). This study also motivates the question of how highly humic ( $>50 \mathrm{mg} \mathrm{C}^{-1}$ ) ecosystems are regulated in tropical regions, since there are still gaps to be filled regarding ecosystem functioning in these environments. Currently, most literature present are focused on humic boreal and temperate lakes ( $>10 \mathrm{mg} \mathrm{Cl}^{-1}$ ) (e.g Gutseit et al. 2007b, Hiltunen et al. 2016) and understanding how primary consumers' community are influenced by DOC/HS additions in broader gradients might help to understand the consequences of future scenarios - since prognostics point out to waters' brownification processes due to climate warming (Larsen et al. 2011).

\section{Acknowledgments}

We would like to thank Conselho Nacional de Desenvolvimento Científico e Tecnológico (CNPq) for the concession of a research grant to RLB and a two-year grant - Master's Degree Funding - without which this research would not happen. We thank the support of Fundação de Amparo à Pesquisa do Estado do Rio de Janeiro (FAPERJ). Also, we would like to acknowledge all the technical and field support given by the staff and professors of the Aquatic Ecology Laboratory in NUPEM (UFRJ). And truly thank Dr. Cláudio Cardoso Marinho, Dr. Albert Suhett, Dr. Vinícius Farjalla and Dra. Ellen Fonte, for the prolific discussions about the influence of humic substances in aquatic communities.

\section{REFERENCES}

AOKI Y, HOSHINO M \& MATSUBARA T. 2007. Silica and testate amoebae in a soil under pine-oak forest. Geoderma 142: 29-35.

ARVOLA L, ELORANTA P, JÖRVINEN M, KESKITALO J \& HOLOPAINEN, AL. 1999. Phytoplankton. In: Kestitalo J and Eloranta P (Eds) Limnology of Humic Substances. Backhuys Publishers, Leiden, p. 137-149.

ATTAYDE JL \& BOZELLI RL. 1998. Assessing the indicator properties of zooplankton assemblages to disturbance gradients by canonical correspondence analysis. Can J Fish Aquat Sci 55: 1789-1797.
AZAM F, FENCHEL T, FIELD JG, GRAY JS, MEYER-REIL LA \& THINGSTAD F. 1983. The ecological role of water-column microbes in the Sea. Mar Ecol Prog Ser 10: 257-263.

BEKKER E, KOTOV A \& TAYLOR D. 2012. A revision of the subgenus Eurycercus (Eurycercus) Baird, 1843 emend. nov.(Cladocera: Eurycercidae) in the Holarctic with the description of a new species. Zootaxa 40: 1-40.

BERGGREN M, ZIEGLER SE, ST-GELAIS NF, BEISNER BE \& GIORGIO PA. 2014. Contrasting patterns of allochthony among three major groups of crustacean zooplankton in boreal and temperate lakes. Ecology 95: 1947-1959.

BOSSUYT BTA, MUYSSEN BTA \& JANSSEN CR. 2005. Relevance of generic and site-specific species sensitivity distributions in the current risk assessment procedures for copper and zinc. Environ Toxicol Chem 24(2): 470-478.

BOZELLI RL, FARIAS D, DE LIMA SKAF, LIRA RTS, NOVA CC, SETÚBAL RB \& SODRÉ EO. 2018. Pequenas áreas úmidas: importância para coservação e gestão da biodiversidade brasileira. Diversidade e Gestão 2(2): 122-138

BRANCO CWC, BALTAZAR ICL, GOMARA G, PINTO G \& FILLIPO R. 2002. Limnological features of Funil Reservoir (RJ, Brazil) and indicator properties of rotifers and cladocerans of the zooplankton community. Lakes Reserv Res Manag 7: 87-92.

BRANCO CWC, KOWSLOWSKI-SUZUKI B \& DEPAGGI SJ. 2005. Rotifers from a humic coastal lagoon of Rio de Janeiro State, Brazil. Stud Neotrop Fauna Environ 4: 255-265.

BRETT MT, KAINZ MJ, TAIPALE SJ \& SESHAN H. 2009. Phytoplankton, not allochthonous carbon, sustains herbivorous zooplankton production. PNAS 106: 21197-21201.

CARLSSON P \& TESTER P. 1995. Influences of riverine humic substances on bacteria, protozoa, phytoplankton, and copepods in a coastal plankton community. Mar Ecol Progr Ser 127: 213-221.

CHAPARRO G, KANDUS P \& O'FARREL I. 2015. Effect of spatial heterogeneity on zooplankton diversity: A multiscale habitat approximation in a floodplain lake. River Res Appl 31: 85-87.

CHOUERI RB, BONECKER CC \& DIAS JD. 2005. Spatial nad temporal diversity variation of microcrustacean assemblages in different systems of the upper Paraná River floodplain (PR/ MS- Brazil). Acta Sci Biol Sci 27: 243-250.

CUNHA-SANTINO MB \& BIANCHINI I. 2004. Oxygen uptake during mineralization of humic substances from Infernão Lagoon (São Paulo, Brazil). Braz J Biol 64: 583-590. 
DEBIASE A \& TAYLOR B. 2005. Microcrustaceans (Branchiopoda and Copepoda) of wetland ponds and impoundments on the Savannah river site, Aiken, South Carolina. Savannah River Ecology Laboratory publication 28: 1-32.

DRUVIETIS I, SPRINGE G \& URTANE L. 1998. Evaluation of plankton communities in small highly humic bog lakes in Latvia. Environ Int 24: 595-602.

DUMONT H \& PENSAERT J. 1983. A revision of the Scapholeberinae (Crustacea: Cladocera). Hydrobiologia 100: 3-45.

DUMOONT HJ \& NEGREA SV. 2002. Introduction to the Class Branchiopoda. Guides to the identification of the microinvertebrates of the continental waters of the World. Vol. 19. Amsterdam: SBP Academic Publishers, 291

p.

ELMOOR-LOUREIRO L. 2000. Ocorrência de Scapholeberis armata Freyi Dumont \& Pensaert (Crustacea, Anomopoda, Daphniidae) no Estado de São Paulo, Brasil. Rev Bras Zool 17: 301-302.

FAITHFULL CL, MATHISEN P, WENZEL A, BERGSTRÖM AK \& VREDE T. 2015. Food web efficiency differs between humic and clear water lake communities in response to nutrients and light. Oecologia 177: 823-835.

FARJALLA VF, AMADO AM, SUHETT AL \& MEIRELLES-PEREIRA F. 2009. DOC removal paradigms in highly humic aquatic ecosystems. Environ Sci Pollut Res 16: 531-538.

FERNANDO CH. 2002. A guide to tropical freshwater zooplankton. Leiden: Backhuys Publishers, 291 p.

GALLOWAY AW ET AL. 2015. A fatty acid based Bayesian approach for inferring diet in aquatic consumers. PLoS ONE 10(6): e0129723.

GUTSEIT K, BERGLUND O \& GRANÉLI W. 2007a. Food quality for Daphnia in humic and clear water lakes. Freshw Biol 52: 344-356.

GUTSEIT K, BERGLUND O \& GRANELI W. 2007b. Essential fatty acids and phosphorus in seston from lakes with contrasting terrestrial dissolved organic carbon content. Freshw Biol 52: 28-38.

HAN B-P, WANG T, LIN Q-Q \& DUMONT HJ. 2007. Carnivory and active hunting by the planktonic testate amoeba Difflugia tuberspinifera. Hydrobiologia 596: 197-201.

HESSEN D, ANDERSEN T \& LYCHE A. 1990. Carbon metabolism in a humic lake: Pool sizes and cycling through zooplankton. Limnol Oceanogr 35: 84-99.
HESSEN DO \& SHARTHAU AK. 1988. Seasonal and spatial overlap between cladocerans in humic lakes. Int Rev Ges Hydrobiol 73: 379-405.

HESSEN D \& TRANVIK LJ (Eds). 2013. Aquatic humic substances: ecology and biogeochemistry. Springer Science \& Business Media. Ecological Studies 133: 361 p.

HESSEN DO \& TRANVIK L. 1998. Humic substances as ecosystem modifiers. In: Hessen DO and Tranvik L (Eds). Aquatic Humic Substances. Springer, Berlin, p. 1-6.

HILTUNEN M, TAIPALE SJ, STRANDBERG U, KAHILAINEN KK \& KANKAALA P. 2016. High intraspecific variation in fatty acids of Eudiaptomus in boreal and subarctic lakes. J Plankton Res 38: 468-477.

JONES R. 1992. The influence of humic substances on lacustrine planktonic food chains. Hydrobiologia 1: 73-91.

KELLY PT, CRAIG N, SOLOMON CT, WEIDEL BC, ZWART JA \& JONES SE. 2016. Experimental whole-lake increase of dissolved organic carbon concentration produces unexpected increase in crustacean zooplankton density. Glob Change Biol 22: 2766-2775.

KELLY PT, SOLOMON CT, WEIDEL BC \& JONES SE. 2014. Terrestrial carbon is a resource, but not a subsidy, for lake zooplankton. Ecology 95: 1236-1242.

KLAVINS M, RODINOV V \& DRUVIETIS I. 2003. Aquatic chemistry and humic substances in bog lakes in Latvia. Boreal Environ Res 8: 113-123.

KOSTE W. 1978. Rotatoria: Die Rädertiere Mitteleuropas. Gebrüder Borntraeger, Berlin.

KRONBERG L. 1999. Content of humic substances in freshwater. In: Kestilato J, Eloranta P (eds) Limnology of humic substances. $1^{\mathrm{a}}$ ed. Backhuys Publishers, Leiden, p. 9-10.

LANSAC-TÔHA FA, VELHO LFM, COSTA DM, SIMÕES NR \& ALVES GM. 2014. Structure of the testate amoebae community in different habitats in a neotropical floodplain. Braz J Biol 74(1): 181-190.

LARSEN S, ANDERSEN T \& HESSEN DO. 2011. Climate change predicted to cause severe increase of organic carbon in lakes. Glob Change Biol 17: 1186-1192.

MACKERETH FJH, HERON J \& TALLING JF. 1978. Water analysis: Some revised methods for limnologists. Freshwater Biology Association 36: 121 p.

MATSUO AY \& VAL AL. 2002. LOW pH and calcium effects on net $\mathrm{Na}+$ and $\mathrm{K}+$ fluxes in two catfish species from the Amazon River (Corydoras: Callichthyidae). Braz J Med Biol Res 35: 361-367. 
MATVEEV V \& ROBSON BJ. 2014. Aquatic food web strucutre and the flow of carbon. Freshw Rev 7: 1-24.

MILLS S ET AL. 2017. Fifteen species in one: deciphering the Brachionus plicatilis species complex (Rotifera, Monogononta) through DNA taxonomy. Hydrobiologia 796: 39-58.

NOGRADY T, WALLACE RL \& SNELL TW. 1993. Rotifera. Volume 1: Biology, Ecology and Systematics. The Hague: SPB Academic Publishing Bv, 299 p.

NOVA CC, BOZELLI RL, SPITZY A \& MÜLLER-NAVARRA D. 2019. Living in a browning environment: Effects on Daphnia's growth and fatty acid pattern. Limnol Oceanogr 64: 18-31.

NÜRNBERG G \& SHAW M. 1998. Productivity of clear and humic lakes: nutrients, phytoplankton, bacteria. Hydrobiologia 382: 97-112.

NUSCH EA \& PALME G. 1975. Biologische Methoden für die Praxis der Gewässeruntersuchung. GWF-Wasser/ Abwasser 116: 562-565.

ORTELLS R, GÓMEZ A \& SERRA M. 2003. Coexistence of cryptic rotifer species: ecological and genetic characterisation of Brachionus plicatilis. Freshw Biol 48: 2194-2202.

PIELOU EC. 1969. An introdution to mathematical ecology. New York: Wiley-Interscience, 286 p.

POURRIOT R. 1977. Food and feeding habits of rotifera. Archiv für Hydrobiologie-Beiheft Ergebnisse der Limnologie 8: 243-260.

RAMSAR. 2018. Ramsar convention on wetlands: State of the World's Wetlands and their Services to People. Gland,Switzerland: Ramsar Convention Secretariat.

R CORE TEAM. 2013. R: A language and environment for statistical computing. R Foundation for Statistical Computing, Vienna, Austria.

ROBIDOUX M, DEL GIORGIO P \& DERRY A. 2015. Effects of humic stress on the zooplankton from clear and DOCrich lakes. Freshw Biol 60: 1263-1278.

ROCHA J \& SARGENTINI E. 1999. Multy-method Study on Aquatic Humic Substances from the "Rio Negro"Amazonas State/Brazil. Emphasis on Molecular-Size Classification of their Metal Contents. J Braz Chem Soc 10: 169-175.

RODRÍGUEZ P, PIZARRO H \& VERA MS. 2012. Size fractionated phytoplankton production in two humic shallow lakes with contrasting coverage of free floating plants. Hydrobiologia 691: 285-298.
RUTTNER-KOLISKO A. 1977. Suggestion for biomass calculations of plankton rotifers. Archiv für Hydrobiologie 8: 71-76.

SANTANGELO JM, ESTEVES FA, MANCA M \& BOZELLI RL. 2014. Disturbances due to increased salinity and the resilience of zooplankton communities: The potential role of the resting egg bank. Hydrobiologia 722: 103-113

SARMA SS, CORRAL-JÁCQUEZ FI, NANDINI S \& BRENABUSTAMANTE P. 2010. Population level indicators of stress: Effects of two heavy metals (copper and mercury) on the growth of lecane quadridentata (Ehrenberg, 1830) (Rotifera: Lecanidae). Journal of Environmental Science and Health - Part A Toxic/Hazardous Substances and Environmental Engineering 45: 32-36.

SARVALA J \& HALSINAHO S. 1990. Crustacean zooplankton of Finnish forest lakesin relation to acidity and other environmental factors. In: Kauppi P, Anttila $P$ and Kenttamies K (Eds) Acidification in Finland. SpringerVerlag, Berlin- Heidelberg, p. 1009-1027.

SARVALA P, KANKAALA P, ZINGEL P \& ARVOLA L. 1999. Zooplankton. In: Keskitalo J and Eloranta P (Eds) Limnology of Humic Waters. Backhuys Publishers, Leiden, p. 173-191.

SCHEFFER M, VAN GEEST GJ, ZIMMER K, JEPPESEN E, SФNDERGAARD M, BUTLER MG, HANSON MA, DECLERCK S \& DE MEESTER L. 2006. Small habitat size and isolation can promote species richness: second-order effects on biodiversity in shallow lakes and ponds. Oikos 112: 227-231.

SEEBENS H, EINSLE U \& SRAILE D. 2013. Deviations from synchrony: spatio-temporal variability of zooplankton community dynamics in a large lake. J Plankton Res 35(1): 22-32.

SEGERS H. 2007. Global diversity of rotifers (Rotifera) in freshwater. Hydrobiologia 595: 49-59.

SOUSA FDR \& ELMOOR-LOUREIRO LMA. 2008. Cladóceros fitófilos (Crustacea, Branchiopoda) do Parque Nacional das Emas, Estado de Goiás. Biota Neotrop 8: 159-166.

STEINBERG C ET AL. 2006. Dissolved humic substances - ecological driving forces from the individual to the ecosystem level? Freshw Biol 51: 1189-1210.

STEINBERG C, MEINELT T, TIMOFEYEV MA \& MENZEL R. 2008a. Humic Substances (review series). Part 2: Interactions with Organisms. Enviro Sci Pollut Res 15: 128-135.

STEINBERG C, SAUL N \& PIETSCH K. 2007. Dissolved humic substances facilitate fish life in extreme aquatic environments and have the potential to extend the lifespan of Caenorhabditis elegans. Ann Environ Sci 1: 81-90. 
STEINBERG CE, TIMOFEYEV MA \& MENZEL R. 2008b. Dissolved Humic Substances : Interactions with Organisms. Environ Sci Pollut Res 15: 128-135.

STEINBERG CEW. 2003. Ecology of Humic Substances in Freshwaters. Springer, Berlin, 440 p.

STEINBERG CEW, OUERGHEMMI N, HERRMANN S, BOUCHNAK R, TIMOFEYEV MA \& MENZEL R. 2010. Stress by poor food quality and exposure to humic substances: Daphnia magna responds with oxidative stress, lifespan extension, but reduced offspring numbers. Hydrobiologia 652: 223-236.

SUHETT AL, AMADO AM, MEIRELLES-PEREIRA F, SCOFIELD V, JACQUES SMS, LAQUE T \& FARJALLA VF. 2013. Origin, concentration, availability and fate of dissolved organic carbon in coastal lagoons of the Rio de Janeiro State. Acta Limnol Bras 25(3): 326-340.

SUHETT AL, MACCORD F, AMADO AM, FARJALLA VF \& ESTEVES FA. 2004. Photodegradation of dissolved organic carbon in humic coastal lagoons (Rio de Janeiro, Brazil). In: MartinNeto L, Milori DMBP and Silva WTL (Eds) Proceedings of the XII Meeting of the International Humic Substances Society. EMBRAPA, São Pedro, p. 61-63.

SUHETT AL, STEINBERG CEW, SANTANGELO JM, BOZELLI RL \& FARJALLA VF. 2011. Natural dissolved humic substances increase the lifespan and promote transgenerational resistance to salt stress in the cladoceran Moina macrocopa. Environ Sci Pollut Res 18: 1004-1014.

VESTERINEN J, SYVÄRANTA J, DEVLIN SP \& JONES RI. 2016. Periphyton support for littoral secondary production in a highly humic boreal lake. Freshw Sci 35: 1235-1247.

WETZEL RG. 2001. Limnology: lake and river ecosystems. $3^{\text {rd }}$ ed. California: Academic Press, 1006 p.

\section{SUPPLEMENTARY MATERIAL}

\section{Appendix A - Figure S1 \\ Appendix B - Table SI}

\section{How to cite}

NOVA CA, ROCHA AM, BRANCO CWC \& BOZELLI RL. 2021. New insights on the relation between zooplankton and humic substances in tropical freshwater ecosystems. An Acad Bras Cienc 93: e20190409. DOI 10.1590/0001-3765202120190409.
Manuscript received on April 8, 2019;

accepted for publication on November 6, 2019

\section{CLARICE C. NOVA ${ }^{1}$}

https://orcid.org/0000-0003-0352-2595

\section{ADRIANA M. ROCHA}

https://orcid.org/0000-0001-6604-563X

\section{CHRISTINA W.C. BRANCO}

https://orcid.org/0000-0002-0509-171X

\section{REINALDO L. BOZELLI ${ }^{1}$}

https://orcid.org/0000-0001-9916-1629

${ }^{1}$ Universidade Federal do Rio de Janeiro, Instituto de Biologia, Departamento de Ecologia, Av. Carlos Chagas Filho, 373, 21940-901 Rio de Janeiro, RJ, Brazil

${ }^{2}$ Universidade Federal do Estado do Rio de Janeiro, Instituto de Biociências, Departamento de Zoologia, Av. Pasteur, 458, 22290-240 Rio de Janeiro, RJ, Brazil

\section{Correspondence to: Clarice Casa Nova}

E-mail: casanova.cla@gmail.com

\section{Author contributions}

Dr. Clarice C. Nova - conceived and designed the analysis; collected the data; performed all analysis; wrote the paper. Dr. Adriana M. Rocha - contributed with analytical tools and ideas discussion; collected the data; final revision. Dr. Christina C.W. Branco - conceived and designed the analysis; helped with zooplankton identification; final revision. Dr. Reinaldo L. Bozelli - conceived and helped with analysis design; collected the data; overall and final revision.

\section{(cc) BY}

